\title{
PENGARUH MOTIVASI DAN KEPUASAN KERJA TERHADAP KINERJA SERTA DAMPAKNYA PADA KARIR DOSEN
}

\author{
Slamet \\ IKIP Veteran Semarang \\ E-mail: slametikipvetsmg@yahoo.co.id
}

\begin{abstract}
Abstrak
Tujuan penelitian untuk mengetahui pengaruh dari: (1) motivasi terhadap kinerja, (2) kepuasan kinerja, (3) motivasi terhadap karir, (4) kepuasan karir, (5) kinerja karir, (6) motivasi dampak kinerja pada karir, dan (7) kepuasan kerja dampak kinerja pada karier dosen di instansi IKIP Veteran Semarang. Jenis penelitian adalah pendekatan kuantitatif korelasional. Hasil penelitian menunjukkan: (1) motivasi kerja memiliki dampak positif dan signifikan terhadap kinerja, (2) kepuasan kerja memiliki dampak positif dan signifikan terhadap kinerja, (3) motivasi memiliki pengaruh positif dan tidak berpengaruh signifikan terhadap karir, (4) kepuasan memiliki pengaruh positif dan dampak yang signifikan terhadap karir, (5) kinerja memiliki pengaruh positif dan signifikan terhadap karir, (6) motivasi memiliki dampak positif dan signifikan terhadap dampak kinerja pada dosen fakultas karir, dan (7) kepuasan kerja memiliki dampak positif dan signifikan terhadap kinerja dosen dampak pada Veteran Semarang IKIP dosen karir.
\end{abstract}

Kata kunci: motivasi kerja, kepuasan kerja, kinerja dosen, karir.

\begin{abstract}
The purpose of research to determine effect of: (1) motivation on performance, (2) the satisfaction of performance, (3) motivation toward a career, (4) satisfaction with career, (5) the performance of career, (6) the motivation of performance impact on career, and (7) job satisfaction the performance impact on faculty careers in IKIP Veteran Semarang. The results showed: (1) motivation to work has a positive and significant impact on performance, (2) job satisfaction has a positive and significant impact on performance, (3) motivation has a positive effect and no significant effect on careers, (4) satisfaction has a positive influence and significant impact on career, (5) performance has a positive and significant influence on the career, (6) motivation has a positive and significant impact on the performance impact on the career faculty lecturer, and (7) job satisfaction has a positive and significant impact on performance lecturers impact on Veteran Semarang Teachers' Training College lecturer career.
\end{abstract}

Keywords: work motivation, job satisfaction, faculty performance, career faculty.

\section{A. Pendahuluan}

Penelitian ini mengkaji secara empirik beberapa permasalahan penting dalam manajemen pendidikan, khusunya manajemen sumber daya manusia (SDM). Lebih-lebih setelah pemerintah mencanangkan berbagai kebijakan pen-didikan yang berorientasi pada peningkatan mutu. Kebijakan 
pemerintah dalam pendidikan itu diberlakukan berdasarkan berbagai analisis, pertimbangan dan prediksi yang realistis, sehingga tujuan utama pendidikan dapat segera ter-wujud secara maksimal.

Berbagai kajian tentang pendidikan menjadi titik tolak penelitian ini, yang umumnya dilihat dari sudut pandang manajemen pendidikan yang memberikan petunjuk pada arti pentingnya pengelolaan sumber daya pendidikan, baik sumber daya manusia, sumber daya keuangan, sumber sarana prasarana maupun sumber daya metode dan prosedur dalam pendidikan (man, money, material, methode).

Dosen merupakan penggerak utama penyelenggaraan pendidikan di perguruan tinggi. Kepemimpinan di jenjang pendidikan dasar, menengah dan tinggi sangat dibutuhkan bagi para dosen dan mahasiswa, karena dosen harus mengajarkan ilmu pengetahuan yang dimilikinya. Di samping itu, dosen juga mendidik mahasiswanya dengan nilai-nilai untuk membentuk kepribadian. Oleh karena itupendidikan yang dimiliki oleh dosen tidak hanya sebatas pada jenjang yang ditempuh sebelum mereka menjadi dosen, tetapi ketika mereka telah menjadi dosen pun diseyogyakan untuk meningkatkan kualitasnya, salah satunya melalui simposium, seminar, dan pelatihan-pelatihan.

Kompetensi yang harus dimiliki seorang dosen kaitannya dengan tugas pengelolaan pembelajaran: (1) memiliki pengetahuan tentang belajar dan tingkah laku mahasiswa serta mampu menterjemahkan ke dalam situasi yang riil, (2) mempunyai sikap yang tepat bagi diri sendiri, kampus, mahasiswa, teman sejawat dan mata kuliah yang ada, (3) menguasai bidang studi yang akan diajarkan, dan (4) mempunyai keterampilan teknis dalam mengajar termasuk di dalamnya penggunaan media. Selain itu dosen dituntut memiliki kompetensi profesional dan mampu mengelola serta mengembangkan kelas secara efektif dan efisien. Sebagai bagian dari kompetensi profesional dosen senantiasa berusaha meningkatkan kualitas mengajar, hal ini merupakan sebuah motivasi yang harus dimiliki oleh seorang dosen. Peningkatan kualitas mengajar tersebut antara lain bisa dipenuhi dengan cara dosen meningkatkan pendidikannya (S2 dan S3) dan 
memanfaaatkan media bagi kepentingan pengajaran yang diwujudkan dengan kinerjanya.

Kaitannya dengan penelitian ini, karena tugas dan kewajiban dosen adalah melaksanakan tri dharma, maka selain mau melakukan tugas utama berupa pendidikan dan pengajaran, dosen juga memiliki motivasi untuk melakukan penelitian dan pengabdian.

Di sisi lain manusia (baca:dosen) memiliki kebutuhan, yang menurut Maslow dapat dikelompokkan menjadi 5 (lima), yaitu: kebutuhan fisiologis sebagai kebutuhan dasar manusia, kemudian secara berurutan kebutuhan rasa aman, kebutuhan sosial, kebutuhan penghargaan diri, dan kebutuhan aktualisasi diri (Uno, 2009). Kaitannya dengan kajian ini, seorang dosen tidak hanya memiliki motivasi instriknsik dan ekstrinsik saja, tetapi juga memiliki kebutuhan lain termasuk kepuasan. Jika dikaitkan dengan teori Maslow, kepuasan termasuk kebutuhan penghargaan diri. Seorang dosen akan merasa puas dalam bekerja bila dalam melaksanakan tugas sesuai dengan harapan, baik intern maupun ekstern. Harapan intern, bila dosen dalam melaksanakan tugas memperoleh imbalan yang sesuai dengan aturan yang ada. Sedangkan harapan dari keluar, mahasiswa dapat memahami ilmu pengetahuan yang diberikan dosen dalam proses pembelajaran. Selain itu, kepuasan tidak hanya berkaitan dengan imbalan (gaji) yang diterima seorang dosen, tetapi juga berkaitan dengan panggilan jiwa. Apabila dosen dalam melaksanakan tugas di dukung sarana dan prasarana yang memadai serta mahasiswa memahami materi yang disampaikan, maka dosen merasa puas sehingga termotivasi untuk melakukan proses pembelajaran sesuai dengan program. Program pengembangan kualitas karir dosen di Indonesia telah dikenal sejak tahun 70-an. Beberapa perguruan tinggi telah menyelenggarakan kegiatan dalam kategori pembinaan karir dosen, seperti penataran khusus untuk dosen baru. Bahkan universitas-universitas tertentu mendirikan pusat pelatihan staf dosen dan menyelenggarakan kegiatan pembinaan karir dosen, baik pada level regional maupun nasional (Mulyasa, 2009).

Undang-Undang Nomor: 14 Tahun 2005 tentang Guru dan Dosen men-syaratkan bahwa dosen perguruan tinggi minimal berpendidikan S2. 
Dalam undang-undang itu juga disebutkan bahwa para pendidik jenjang pendidikan dasar dan menengah minimal bergelar S1, sementara untuk mendidik di jenjang pendidikan akademis S1, sekurang-kurangnya harus bergelar strata dua (S2), sedangkan bagi program pascasarjana adalah doktor (S3) dan profesor. Kenyataan tersebut ironis, mengingat salah satu cita-cita besar perguruan tinggi di Indonesia adalah menjadi universitas bertaraf internasional (world class university). Dengan adanya 30\% dosen yang masih berkualifikasi S1, sulit dalam waktu dekat meng-gapai cita-cita tersebut (Miarso, 2010). Apalagi di tengah kondisi demikian, tidak tampak upaya signifikan dari para dosen untuk meningkatkan profesionalitas dan karirnya sebagai elemen pokok dari sebuah perguruan tinggi. Bahkan sebagian dosen kurang menyadari bahwa profesi dosen sebagaimana profesi lain, juga terkait dengan dimensi pengetahuan, keahlian, dan etika yang perlu terus dikembangkan dalam karirnya. Dengan demikian dapat dikemukakan bahwa ada sebagian dosen yang dalam pelaksanaan tugasnya kurang maksimal sebagai akibat kurangnya daya dukung SDM yang dimiliki, sehingga karir dosen tidak dapat tercapai secara maksimal.

Berkaitan kemampuan dosen dalam meningkatkan kinerja dan karirnya, ada beberapa fenomena menarik untuk dikaji. Salah satunya adalah motivasi untuk melakukan studi lanjut (S2 dan S3) dan meningkatnya kemampuan dalam memenuhi kompetensinya. Hal ini penting untuk dibahas, karena sebagian dosen yang mengajar hanya sebagai pelaksanaan tugas dan kewajiban belaka, dan belum sampai pada pemikiran kualitas pembelajaran. Upaya untuk meningkatkan kompetensi profesionalnya baik dengan pelatihan akademik maupun kegiatan penggunaan media dan inovasi dalam pembelajaran masih menjadi kendala bagi sebagian dosen, hal ini dapat terjadi karena kurang motivasi dari dalam diri dosen itu dan juga kurangnya motivasi dari pimpinan. Mengacu pada pemikiran ter-sebut, seorang dosen harus memiliki motivasi (intern dan ekstern). Apabila motivasi dimiliki oleh setiap dosen, maka akan tercipta suasana pembelajaran yang maksimal dan berdampak pada prestasi belajar yang dicapai oleh mahasiswa, sehingga akan tercipta kepuasan kepada semua pihak, baik dosen itu sendiri, mahasiswa, orang 
tua, pimpinan dan lembaga. Demikian pentingnya dosen hingga tidak sedikit perguruan tinggi menjadi terkenal karena kemasyhuran para dosen yang bekerja di dalamnya.

Berdasar uraian di atas dapat dikemukakan bahwa dosen yang memiliki motivasi tinggi, maka dosen akan merasa bangga ketika dalam pelaksanaan pembelajaran diperoleh suatu keberhasilan. Perolehan ini akan membuat dosen merasa senang, sehingga secara psikologis memberikan motivasi tersendiri. Apabila kondisi demikian dimiliki dan dilakukan oleh semua dosen, maka secara tidak langsung kompetensi profesional dosen akan terwujud. Hal ini ditunjukkan oleh kinerjanya berupa pelaksanaan tugas dan kewajiban dalam proses pembelajaran. Namun karena kondisi di lapangan kadang ditemui kendala, sehingga pemikiran ideal tersebut tidak dapat terlaksana dengan baik dan maksimal. Sementara, semua pelaksanaan tugas berkaitan dengan karirnya, baik itu ditunjang oleh SDM-nya melalui pendidikan S2 dan S3, kemampuan profesional akademik serta peningkatan jabatan fungsional (Jafa). Dengan dengan demikian muncul pertanyaan; bagaimana pengaruh: (1) motivasi kerja terhadap kinerja dosen?, (2) kepuasan kerja terhadap kinerja dosen?, (3) motivasi kerja terhadap karir dosen?, (4) kepuasan kerja terhadap karir dosen?, (5) kinerja terhadap karir dosen?, (6) motivasi kerja terhadap kinerja serta dampaknya pada karir dosen?, dan (7) kepuasan kerja terhadap kinerja serta dampaknya pada karir dosen IKIP Veteran Semarang?

\section{B. Motivasi Kerja}

Motivasi kerja dapat diartikan sebagai kekuatan atau energi seseorang yang dapat menimbulkan tingkat persistensi dan antusiaisme dalam melaksana-kan kegiatan, baik yang bersumber dari dalam diri individu itu sendiri (instrinksik) maupun dari luar individu (ekstrinsik). Seberapa kuat motivasi yang dimiliki individu akan banyak menentukan terhadap kualitas perilaku yang ditampilkan, baik dalam konteks belajar, bekerja maupun dalam kehidupan sehari-hari lainnya. 
Menurut Abraham H. Maslow dalam Simamora (2009); setiap manusia setidaknya memiliki 5 (lima) kebutuhan, yaitu: (1) kebutuhan fisiologis, seperti: makan dan minum, pakaian, perumahan, dan kesehatan; (2) kebutuhan rasa aman, setiap individu memerlukan kebutuhan rasa aman, perlindungan dari ancaman, bahaya, pertentangan dan lingkungan hidup; (3) hubungan sosial, kebutuhan ini berkaitan dengan rasa memiliki, diterima dalam kelompok, berafiliasi, berinteraksi dan mencintai serta dicintai orang lain; (4) kebutuhan penghargaan diri, bahwa setiap manusia memiliki kebutuhan berkaitan dengan penghargaan diri, dihormati dan dihargai orang lain; dan (5) kebutuhan aktualisasi diri, yaitu kebutuhan untuk menggunakan skill, potensi, berpendapat, memberikan penilaian dan kritik terhadap sesuatu.

\section{Kepuasan Kerja}

Dalam manajemen pendidikan bahwa keberhasilan pendidikan tidak hanya karena faktor kurikulum, sarana-prasarana, lembaga dan intelektualitas mahasi-swa, namun peran dosen juga perlu mendapatkan perhatian. Mengingat dosen harus berperan aktif dalam merangsang mahasiswa untuk berhasil dalam kegiat-an pembelajaran, maka dosen sebagai "manusia pekerja" perlu memiliki motivasi yang dapat mendorong untuk eksis dalam pekerjaanya. Kepuasan kerja (job satisfaction) merupakan salah satu sikap kerja dosen yang perlu diciptakan dalam sebuah perguruan tinggi agar dapat bekerja dengan moral yang tinggi, disiplin, semangat, berdedikasi dan menghayati profesinya. Dosen yang merasa puas terhadap lembaganya dan tempat bekerja, akan berdampak pada kelancaran kegiatan pembelajaran dan peningkatan kualitas layanan kepada mahasiswa.

Dalam dunia pendidikan dapat terjadi seperti kasus pada suatu perusahaan, mengingat lembaga pendidikan dapat dianggap sebagai sebuah perusahaan yang memproduksi sumber daya manusia (SDM). Jika kepuasan kerja dosen tidak ter-jamin, maka dosen bisa saja akan mangkir, membolos dari mengajar karena protes terhadap ketidakpuasan yang diperolehnya. Oleh karena itu pimpinan harus berusaha untuk memahami para dosen dan 
mengupayakan agar dosen memper-oleh kepuasan dalam menjalankan tugasnya.

Kepuasan kerja (job satisfaction) adalah cara seorang pekerja merasakan pekerjaanya. Kepuasan kerja merupakan generaralisasi sikapsikap terhadap pekerjaan yang didasarkan aspek perkerjaan yang bermacam-macam (Raymond, 2010). Kepuasan kerja juga sebagai suatu sikap positif dan juga bisa negatif yang dimiliki individu terhadap berbagai segi pekerjaan, tempat kerja, dan kontribusi dengan teman sejawat. Hal ini dihasilkan dari faktor instrinsik dan ekstrinsik serta persepsinya terhadap pekerjaan (Gibson, Ivancevich dan Donelly, 2007).

Kepuasan kerja juga merujuk pada sikap umum seorang individu yang menilai perbedaan antara jumlah imbalan yang diterima dengan seharusnya yang diyakini akan diterima. Individu yang mempunyai kepuasan kerja tinggi memiliki sikap positif terhadap kerja, sebaliknya individu yang tidak puas dengan pekerja-annya memiliki sikap negatif terhadap pekerjaannya (Robbins, 2005). Pengertian tersebut memberikan gambaran bahwa kepuasan kerja merujuk pada keadaan emosi yang positif dari mengevaluasi pengalaman kerja seseorang.

Ada 5 (lima) model yang dapat mempengaruhi penyebab kepuasan kerja (Pasaribu, 2008), yaitu: (1) pemenuhan kebutuhan, bahwa kepuasan ditentukan karakteristik sebuah pekerjaan yang memungkinkan seseorang untuk memenuhi kebutuhannya, kebutuhan yang tidak terpenuhi akan dapat mempengaruhi kepuasan kerja; (2) ketidakcocokkan, kepuasan adalah hasil dari harapan yang terpenuhi. Pada saat harapan lebih besar dari yang diterima, seseorang akan tidak puas. Sebaliknya, individu akan puas pada saat ia mempertahankan ouput yang diterima dan melampui harapan pribadinya; (3) pencapaian nilai, gagasan yang melandasi pencapaan nilai adalah kepuasan yang berasal dari persepsi terhadap suatu pekerjaan yang memungkinkan untuk pemenuhan nilai-nilai kerja yang penting dari seseorang. Oleh karena itu para manajer dapat meningkatkan kepuasan kerja dengan melakukan strukturisasi lingkungan kerja, penghargaan dan pengakuan yang berhubungan dengan nilai-nilai kerja karyawan; (4) persamaan, dalam model ini, kepuasan adalah suatu fungsi 
dari seorang individu untuk diperlakukan secara adil di tempat kerja. Kepuasan berasal dari persepsi seseorang bahwa ouput pekerjaan relatif sama dengan inputnya, perbandingan yang mendukung output atau input lain yang signifikan; dan (5) komponen watak atau genetic, model ini didasarkan pada keyakinan bahwa kepuasan merupakan sebagian fungsi dari sifat pribadi maupun faktor genetik. Hal ini menunjukkan bahwa perbedaan individu yang stabil adalah sama pentingnya dalam menjelaskan kepuasan kerja dengan karakteristik lingkungan kerja.

\section{Kinerja Dosen}

Kinerja adalah suatu pandangan dan sikap seseorang atau suatu bangsa terhadap suatu pekerjaan (Anoraga, 2008). Pendapat lain, kinerja adalah perbandingan antara hasil yang telah dicapai dengan peran serta tenaga kerja persatuan waktu (Kusriyanto, 2007). Menurut Luis Sabuorin dalam Asian Produktivity Congress (1980), kinerja adalah rasio dari yang dihasilkan (out-put) terhadap seluruh yang digunakan (in-put) untuk mendapat hasil. Sanjaya (2008) membagi pengertian kinerja menjadi dua, yaitu: (1) inerja sebagai perbandingan terbalik antara hasil yang digunakan dengan jumlah sumber kerja yang diperguna-kan. Pada kinerja ini tolak ukurnya adalah uang dan setiap sumber kerjanya yang dipergunakan harus dinilai uang; dan (2) kinerja yang diukur dari daya guna penggunaan metode atau cara kerja dan alat-alat, sehingga volume dan beban kerja dapat diselesaikan dengan waktu yang tersedia. Berdasarkan pendapat tersebut, hasil yang diperoleh bersifat non-meterial yang tidak dapat di ukur dengan uang, sehingga kinerja hanya dapat digambarkan melalui efisien personal dalam melaksanakan tugas-tugas pokoknya. Kinerja tidak dapat di hitung secara eksak, karena masuk dan keluarnya sebagian besar bersifat abstrak.

Materi penilaian kinerja dosen ini berdasarkan pada tugas yang harus dilakukan sesuai Tri Dharma Perguruan Tinggi, yaitu (1) pendidikan dan peng-ajaran, (2) penelitian, dan (3) pengabdian pada masyarakat, serta penambahan yaitu (4) loyalitas sebagai pendukung. Secara rinci indikatorindikator tersebut dijabarkan dalam Kepmenkowasbangpan Nomor 
Jurnal Pendidikan Agama Islam

38/1999 tentang Juknis Pelaksanaan Penilaian Angka Kredit Jabatan Dosen yang diperkuat dengan Kepmendiknas Nomor: 36/D/0/2001.

\section{E. Karir Dosen}

Pengertian karir adalah profesi yang dimiliki oleh seseorang berkaitan dengan pekerjaan yang digelutinya setiap hari. Karir tidak hanya sekedar profesi atau pekerjaan, tetapi juga berkaitan dengan pengembangan dan kemajuan-kemajauan dari bidang yang digeluti di masa mendatang dengan harapan yang lebih baik dan positif (Sukmadinata, 2008). Jika dikaitkan dengan penelitian ini, harapan dan tuntutan terhadap pentingnya profesionalitas seorang dosen, menunjukkan betapa pentingnya seorang dosen menyadari penting arti profesi sebagai karir yang disandangnya. Realitas menunjukkan bahwa ternyata sikap profesional yang dimiliki oleh seorang dosen ternyata jauh dari yang diharapkan oleh Undang-Undang Guru dan Dosen No.14 tahun 2005, selain disebabkan karena bervariasinya jenjang pendidikan yang rata-rata masih pada tingkat magister (S2) ke bawah (S1), juga karena masih terdapatnya sejumlah dosen yang memiliki kinerja yang masih lemah. Kinerja yang rendah ini ditandai dengan jumlah kehadairan tatap muka di kelas yang masih rendah, persiapan mengajar yang sedanya, sampai kepada kehadiran dan partisipasinya pada kegiatan ilmiah, dan jurusan.

Karir dosen ini dapat diukur dan dilihat dari: (1) jabatan structural yang dipercayakan kepada seorang dosen, (2) jabatan fungsional (Jafa) dosen, (3) jabatan akademik dosen.

\section{F. Kerangka Pikir}

Kerangka pemikiran teoretis dalam penelitian ini dapat diperjelas dengan bentuk bagan seperti dikemukakan berikut ini: 
Motivasi kerja $\left(\mathrm{X}_{1}\right)$

1. Kebutuhan fisiologis

2. Kebutuhan rasa aman

3. Hubungan sosial

4. Penghargaan diri

5. Aktualisasi diri

Kepuasan kerja $\left(\mathrm{X}_{2}\right)$

1. Pemenuhan kebutuhan

2. Ketidakcocokan

3. Pencapaian nilai

4. Persamaan

5. Komponen watak/ genetik

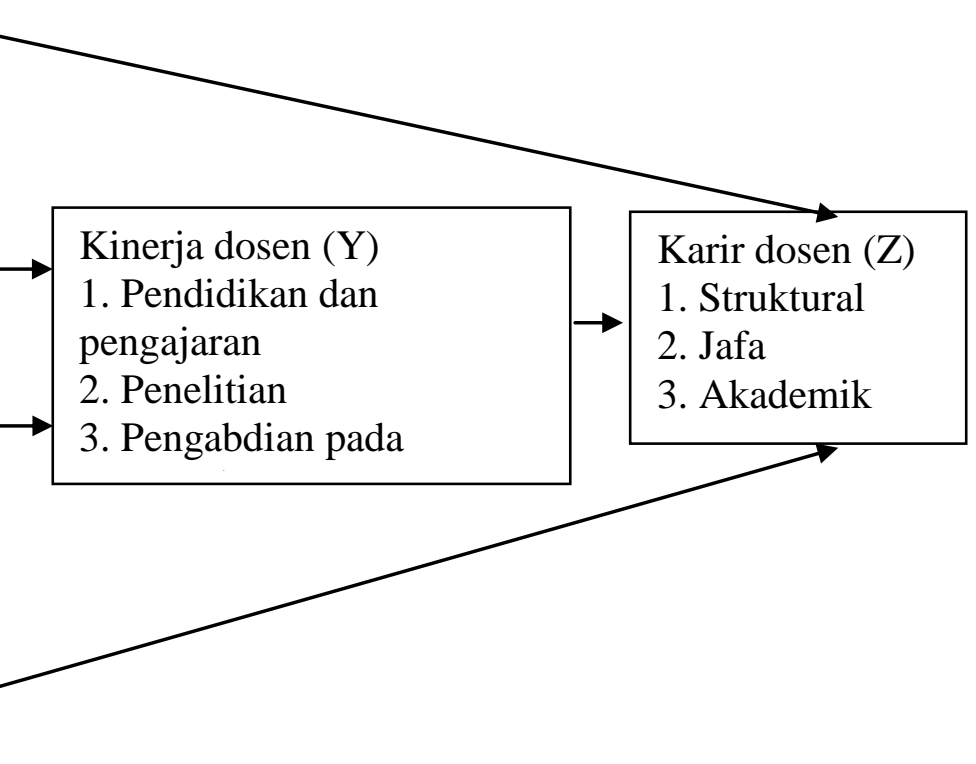

Gambar 2.1: Bagan Kerangka Pikir

\section{G. Metode Penelitian}

Jenis penelitian yang digunakan adalah kuantitatif, sebab untuk menguji teori, menguji hipotesis, penggunaan alat uji statistik digunakan angka-angka dengan pengolahan data statistik, bahkan mulai dari pengumpulan data, penafsiran data serta penyajiannya dilakukan dalam bentuk dan model angka-angka berdasarkana hasil olahan statistik pula (Arikunto, 2012: 106) Sedangkan desain yang digunakan menggunakan model analisis jalur (path analysis). Analisis jalur bertujuan menerangkan akibat langsung dan tidak langsung seperangkat variabel, sebagai variabel penyebab terhadap seperangkat variabel lain sebagai variabel terikat.

Subjek penelitian adalah seluruh dosen IKIP Veteran Semarang, baik yang berstatus sebagai dosen Yayasan maupun dosen PNS Kopertis Wilayah VI Jawa Tengah yang diperbantukan di IKIP Veteran Semarang. Seluruh populasi berjumlah 98 orang, sehingga semuanya dijadikan sebagai subjek dengan teknik sampling yang digunakan adalah total sampling atau kasus.

Mengingat variabel yang diukur adalah skala ordinal, sehingga diperlukan persyaratan-persyaratan sebagai berikut: 
1) Uji Normalitas

Uji normalitas adalah untuk melihat apakah nilai residual terdistribusi normal atau tidak. Model regresi yang baik adalah memiliki nilai residual yang terdistribusi normal. Jadi uji normalitas bukan dilakukan pada masing-masing variabel, tetapi pada nilai residualnya. Model yang baik adalah data yang ter-distribusi normal. Uji normalitas yang digunakan dalam penelitian ini adalah dengan melakukan uji kecekungan kurva (Skewnes) terhadap data yang dimiliki. Hal ini dimaksudkan untuk mengetahui normal atau tidaknya sebaran data yang akan dianalisis.

2) Analisis Deskriptif

Teknik analisis deskriptif digunakan untuk mendeskripsikan atau meng-gambarkan data ke dalam perhitungan rerata (mean), simpangan baku (standard deviasi), rentangan (range), dan perhitungan statistik deskriptif lain. Dalam penelitian ini, analisis deskriptif yang digunakan adalah analisis deskriptif persentase (DP), yang dimaksudkan untuk memperoleh gambaran tentang penyebaran hasil penelitian dari masingmasing variabel dengan ukuran atau kategori tertentu.

3) Analis Jalur

Rutherford (1993) seperti dikutip Setiaji (2008) mengemukakan bahwa analis jalur adalah suatu teknik untuk menganalisis hubungan sebab-akibat yang terjadi pada regresi berganda jika variabel bebasnya mempengaruhi variabel tergantung tidak hanya secara langsung. Dikemukakan lebih lanjut bahwa analis jalur merupakan pengembangan langsung bentuk regresi berganda dengan tujuan untuk memberikan estimasi tingkat kepentingan (magnitude) dan signifikansi (significance) hubungan sebab akibat hipotetikal dalam seperangkat variabel.

\section{H. Pembahasan}

1) Pengaruh Motivasi Kerja terhadap Kinerja Dosen

Pengaruh motivasi kerja terhadap kinerja dosen diperoleh skor sebesar 0,430, hal ini menunjukkan bahwa motivasi kerja yang dimiliki dan dilakukan oleh dosen IKIP Veteran Semarang sangat berpengaruh terhadap kinerja dosen. Hal tersebut dapat dijelaskan bahwa motivasi kerja 
pimpinan dan motivasi kerja yang dimiliki oleh seorang dosen akan memberikan pengaruh kuat terhadap kinerja dosen. Kondisi tersebut ini bisa terjadi, sebab dosen merasa diperhatikan oleh pimpinan, sehingga dosen mengimbangi dengan melakukan kerja berupa proses pembelajaran dengan baik dan maksimal. Hal tersebut bila dikaitkan dengan instrumen yang mengupasnya, motivasi kerja tidak hanya ditunjukkan dengan pelaksanaan proses pembelajaran saja, tetapi juga kegiatan lain seperti halnya pemberian motivasi kepada mahasiswa. Selain pengajaran (pendidikan), dosen juga melakukan penleitian dan pengabdian pada masyarakat sebagai pelaksanaan Tri Dharma Perguruam Tinggi, yang bertujuan untuk pengembangan diri dan menunjang tugas utamanya sebagai pengajar. Diharapkan temuan penelitian yang dilakukan dan pengabdian yang dilakukan dapat memberikan wawasan yang tidak hanya dari teori-teori yang di baca dari buku saja, tetapi juga diperoleh terapanterapan di lapangan.

Selain itu juga komunikasi dengan luar, selain tugas utama pengajaran, dosen juga melakukan pendekatan kepada masyarakat melalui komunikasi untuk mengetahui kekurangan-kekurangan dan kelebihan, baik yang diperoleh di bangku kuliah maupun kebiasaan yang dilakukan oleh mahasiswa sehari-hari di dalam keluarga atau dalam masyarakat. Artinya, selain adanya pengajaran dan penelitian, dosen juga diseyogyakan untuk berkomunikasi dengan masyarakat. Hal ini dapat terwujud dalam bentuk kerja sama dengan masyarakat seperti halnya penyuluhan-penyuluhan dalam peng-abdian, sehingga selain menerapkan ilmu yang dimiliki, dosen juga mendapatkan tambahan pengetahuan dan pengalaman yang terjadi di lapangan, yaitu di dalam masyarakat. Inilah wujud nyata dari kinerja dosen, selain motivasi yang dimiliki secara pribadi, karena ingin mengembagkan ilmunya, juga diperoleh motivasi dari pimpinan yang mampu membangkitkan gariah dosen untuk bekerja. Bila dikaitkan dengan hasil angka sebesar 0,430, maka bisa dijabarkan semakin tinggi atau semakin baik motivasi kerja yang dimiliki oleh para dosen, maka akan diikuti dengan peningkatan kinerja dosen sebesar 43\% dari seluruh item atau indikator yang mempengaruhinya. 
2) Pengaruh Kepuasan Kerja terhadap Kinerja Dosen

Pengaruh kepuasan kerja terhadap motivasi kerja guru diperoleh sebesar 0,572, hal ini bisa diberikan penjelasan bahwa kepuasan kerja berkaitan dengan kinerja dosen. Kepuasan kerja dapat terjadi di lembaga maupun lingkungan tempat bekerja. Bahkan bila dikaji secara mendalam, lingkungan kerja tersebut berkaitan dengan iklim atau suasana komunikasi serta hubungan, baik dengan sesama dosen, dengan pimpinan maupun kepada mahasiswa. Bila dikaitkan dengan item-item yang mengupasnya, kepuasan kerja berbicara suasana kerja, motivasi, lingkungan dan sarana serta prasarana sebagai pendukung. Hal ini menunjukkan bahwa dosen perlu membina hubungan dengan lingkungan, suasana kampus yang "nyaman" dan penuh dengan kekeluargaan akan membawa dampak positrif terhadap kepuasan kerja dosen. Bila dilihat dari angka yang diperolehnya sebesar 0,572, hal ini berarti semakin baik kepuasan kerja yang dimiliki oleh dosen, maka akan semakin berpengaruh terhadap kinerja dosen sebesar 57,2\%, disamping faktor lain yang mempengaruhinya.

Berdasarkan indikator atau item-item yang mengupasnya dapat diketahui bahwa suasana kekeluargaan dengan sesama dosen, dosen dengan pimpinan (Rektoriat, Dekanat, dan Kaprogdi) dan bahkan dengan mahasiswa, selama masih dalam koridor dan batas-batas kewajaran, maka hubungan tersebut sah-sah saja, bahkan untuk paradigma pendidikan sekarang dianjurkan, sebab konsep pendidikan sekarang posisi mahasiswa tidak hanya sebagai tempat trasfer ilmu, tetapi mahasiswa menjadi teman atau patner dosen. Dosen tidak akan ber-kembang, bila tanpa mendapat masukan dari mahasiswa, melihat kondisi lapangan sebagai sasasaran atau publik yang membutuhkan lulusan, dengan demikian lulusan tidak hanya sekedar lulus saja, tetapi juga diberikan bekal kehidupan di dalam masyarakat, harapannya setelah mahasiswa lulus dapat diterima di setiap lapisan, baik oleh masyarakat tempat mahasiswa tersebut berada maupun lingkungan pekerjaan sebagai eksistensi pengabdiannya kelak. Inilah pentingnya kondisi lingkungan yang keberadaannya tidak bisa diabaikan dalam mempengaruhi kinerja dosen. 
3) Pengaruh Motivasi Kerja terhadap Karir Dosen

Pengaruh motivasi kerja terhadap karir dosen diperoleh angka koefisien beta standar sebesar 0,178, namun dalam signifikan diperoleh angka sebesar 0,128 yang berarti memiliki pengaruh positif tetapi tidak signifikan. Dengan demikian dapat dijelaskan bahwa, karena hasil hitung pengaruh motivasi kerja terhadap karir dosen diperoleh signifikansi 0,128 dan angka tersebut lebih besar dari pada angka tabel $\alpha=5 \%(0,05)$ maka dapat dibuat persamaan: 0,128 $>0,05$. Mengingat hasil hitung kurang dari atau lebih kecil dari angka dalam tabel, maka dapat dikemukakan bahwa motivasi kerja tidak memiliki pengaruh yang signifikan terhadap karir dosen. Hal tersebut bisa terjadi, sebab motivasi tidak hanya motivasi yang bersifat instrinsik dari dosen itu sendiri, tetapi bisa berasal dari luar, baik itu atasan langsung maupun orang-orang yang ada di sekitarnya, sehingga bisa saja terjadi dosen telah memiliki motivasi kuat untuk meningkatkan karirnya, tetapi orang-orang yang ada di sekitarnya tidak memberikan motivasi, sehingga dosen akan kurang semangat dalam bekerja dan akibatnya terjadi karir yang tidak meningkat. Oleh sebab itu, ke depan dosen harus memiliki motivasi individu yang kuat, tidak perlu iri atau tidak perlu melihat sesama dosen yang tidak menunjukkan kinerjanya dengan baik, baik berkaitan dengan tugas utama pembelajaran, penelitian maupun pengabdian kepada masyarakat sebagai wujud nyata dari pelaksanaan Tri Dharma Perguruan Tinggi.

4) Pengaruh Kepuasan Kerja terhadap Karir Dosen

Pengaruh kepuasan kerja terhadap karir dosen diperoleh hasil sebesar 0,300, hal ini bisa diberikan penjelasan bahwa kepuasan kerja berkaitan dengan kinerja yang dilakukan oleh dosen berupa pelaksanaan pembelajaran, selain adanya pengabdian dan penelitian. Bahkan bila dikaji mendalam, kepuasan kerja berkaitan dengan suasana batin seseorang (dosen) dalam melakukan tugas dan kewajibannya sebagai dosen. Bila dikaitkan dengan item-item yang mengupas-nya, kepuasan berkaitan dengan pemuasan kebutuhan dasar seorang dosen baik itu pemenuhan fisiologis, kebutuhan primer dan skunder, rasa aman, perlindungan dan sebagainya. Sedangkan karir dosen berkaitan dengan jabatan fungsional, 
jabatan struktural, dan peningkatan akademik lainnya. Oleh sebab itu jika seorang dosen memiliki motivasi kerja, maka diharapkan dapat memberikan motivasi berkaitan dengan pelaksanaan tugas tri dharma, oleh sebab itu jika kebutuhan pokok seorang dosen telah terpenuhi, maka harapannya dapat mengejar karirnya, dan ini ditunjukkan dengan skor yang diperoleh sebesar 0,300 atau 30\% darei seluruh item yang mengupas tentang kedua variabel tersebut. Dengan demikian secara singkat dapat dikemukakan bahwa semakin baik motivasi kerja yang dimiliki seorang dosen, maka akan diikuti kenaikan sebesar 30\% dari karir yang dimiliki seorang dosen.

\section{5) Pengaruh Kinerja terhadap Karir Dosen}

Pengaruh kinerja terhadap karir dosen diperoleh $t$ hitung sebesar 0,561. Angka tersebut jauh lebih tinggi di atas variabel-variabel lain, ini menunjukkan bahwa kinerja yang dimiliki oleh dosen akan dapat memicu dosen untuk bekerja lebih giat dan lebih baik lagi. Hal tersebut bila dikaitkan dengan indikator atau item-item yang menguaps di dalam angket, maka dapat dijabarkan bahwa kinerja dosen dapat dikupas dari tugas kewajiban pembelajaran, penelitian, pengabdian, dan tugas penunjang lain sebagai bentuk pelaksanaan loyalitas baik terhadap pimpinan maupun tugas kelembagaan.

Tidak bisa dipungkiri bahwa dosen dalam melaksanakan tugas dan kewajibannya selalu berkaitan dengan tugas tri dharma. Bila seseorang cinta dengan pekerjaannya, maka akan melaksanakan tugas pekerjaan tersebut dengan maksimal. Hal ini tentu akan diimbangi dan diwujudkan dalam bentuk kinerja, maka tidak mengherankan jika kinerja yang dimiliki oleh dosen tersebut akan berpengaruh terhadap karirnya. Hal ini didukung t hitung atau hasil hitung sebesar 0,561, ini menunjukkan bahwa kinerja dosen lebih besar bila dibanding-kan dengan faktor atau variabel lain, yang sekaligus memberikan arti bahwa semakin meningkat kinerja yang dimiliki para dosen maka akan semakin meningkat karirnya yang ditunjukkan berupa pelaksanaan proses pembelajaran. Adapun penjelasan faktor pendukung adalah, selain dosen memiliki tugas dan kewajiban sebagai pelaksana tri dharma, dosen juga melaksanakan tugas lainnya sebagai 
pendukung dari kewajiban yang harus di laksanakan, di antara tugas-tugas pendukung tersebut adalah menjadi anggota senat, menjadi anggota profesi, memberikan pelatihan di luar lembaga yang semuanya dikaitkan dengan karir sebagai seorang dosen. Dengan demikian secara keseluruhan dapat dikemukakan bahwa pengaruh kinerja dosen terhadap karir dosen sebesar 0,561 atau 56,1\% yang didukung oleh item-item yang mengupasnya.

6) Pengaruh Motivasi Kerja terhadap Kinerja serta Dampaknya pada Karir Dosen

Pengaruh motivasi kerja terhadap kinerja serta dampaknya pada karir dosen IKIP Veteran Semarang diperoleh skor sebesar 0,223 lebih besar dari pengaruh langsung sebesar 0,178, hal ini menunjukkan bahwa motivasi kerja yang dimiliki dan dilakukan oleh seorang dosen sangat berpengaruh terhadap kinerja dosen yang berdampak pada karir dosen. Hal tersebut dapat dijelaskan bahwa motivasi kerja dari pimpinan akan sangat memberikan warna atau pengaruh kuat terhadap motivasi kerja dosen yang diwujudkan dalam kinerjanya berupa pelaksanaan proses pembelajaran. Hal ini dapat dikemukakan, sebab dosen merasa diperhatikan oleh pimpinan yaitu Rektor, Dekan atau Kaporgdi, sehingga dosen harus berusaha untuk memiliki motivasi dalam bekerja yang diwujudkan melalui kinerjanya berupa proses pembelajaran yang baik dan maksimal. Hal ini jika dikaitkan dengan instrumen yang mengupasnya, motivasi kerja tidak hanya ditunjukkan dengan pelaksanaan proses pembelajaran saja, tetapi juga kegiatan lain seperti halnya pemberian motivasi kepada mahasiswa.

Selain pelaksanaan proses pembelajaran, dosen juga mengembangkan potensinya dan melakukan penelitian serta pengabdian yang bertujuan untuk pengembangan diri dan menunjang tugas utamanya sebagai pengajar. Diharapkan temuan penelitian yang dilakukan dapat memberikan masukan dan wawasan untuk diterapkan di lapangan. Ini menunjukkan bahwa selain adanya pengajaran dan penelitian, dosen juga diseyogyakan untuk melaksanakan pengabdian di dalam masyarakat. Hal ini dapat terwujud dalam bentuk kerja sama dengan masyarakat, seperti halnya memberikan penyuluhan-penyuluhan, sehingga selain menerapkan ilmu 
Jurnal Pendidikan Agama Islam

yang dimiliki, dosen juga mendapatkan tambahan pengetahuan dan pengalaman yang diperoleh di lapangan, yaitu di dalam masyarakat. Inilah wujud nyata dari kinerja dosen, selain motivasi yang dimiliki secara pribadi, karena ingin mengembagkan ilmunya, juga diperoleh motivasi dari pimpinan yang mampu membangkitkan gariah dosen untuk bekerja berupa pelaksanaan proses pembelajaran, sebagai perwujudan karir yang dimilikinya.

7) Pengaruh Kepuasan Kerja terhadap Kinerja serta Dampaknya pada Karir Dosen

Pengaruh kepuasan kerja terhadap kinerja serta dampaknya pada karir dosen diperoleh skor sebesar 0,295, angka ini lebih kecil atau kurang dari pengaruh langsung sebesar 0,300, hal ini bisa diberikan penjelasan bahwa kepuasan kerja tidak memediasi terhadap kinerja dosen yang berdampak pada karir dosen IKIP Veteran Semarang. Bila dikaitkan dengan suasana kerja di IKIP Veteran Semarang, hal tersebut berkaitan dengan iklim atau suasana kerja serta hubungan dengan dosen lain, baik dengan sesama dosen dan pimpinan terlebih-lebih dengan mahasiswa. Apabila dikaitkan dengan item-item yang mengupasnya, kepuasan kerja berkaitan dengan masalah financial dan non finansial, hal ini berarti berkaitan dengan hal-hal yang dapat diukur dan tidak dapat diukur, termasuk dalam suasana kerja dengan membina hubungan dengan orang lain. Hal ini menunjukkan bahwa dosen perlu membina hubungan dengan lingkungan, suasana akademik yang baik dan nyaman serta penuh dengan kondusif seperti halnya tercipta rasa kekeluargaan yang ditengarai akan membawa dampak positif pada kinerja seorang dosen.

Berdasarkan indikator atau item-item yang mengupasnya dapat diketahui bahwa suasana akrab dosen dengan sesama dosen, dosen dengan kepala pimpinan (Rektoriat, Dekanat, Kaprogdi) dan bahkan dengan mahasiswa. Terkhusus hubungan antara dosen dengan mahasiswa tersebut, selama masih dalam koridor dan batas-batas kewajaran sebagai hubungan bapak-anak, maka hubungan tersebut diijinkan bahkan disarankan. Hal tersebut perlu dilakukan dan diwujudkan, sebab paradigma pembelajaran sekarang berubah, yaitu mahasiswa adalah pusat pembelajar; "student 
centris". Oleh sebab itu dosen harus mengubah pemikiran lama yang konvensional, dosen tidak memberikan materi secara penuh, tetapi mahasiswa diberi kesempatan untuk menampilkan ide-ide dan pendapatnya yang berkaitan dengan materi pembelajaran yang tentu disesuaikan dengan kondisi lingkungan. Inilah pentingnya komunikasi yang dilakukan oleh dosen kepada mahasiswa. Sedangkan komunikasi dengan sesama dosen yang dapat memberikan motivasi dan masukan serta saling mengisi kekurangan dosen lain, sehingga suasana kekeluargaan tidak hanya tercipta dalam buda atau lingkungan kampus saja, tetapi secara individu juga memiliki ikatan batin dan kekeluargaan. Sedang komunikasi dengan pimpinan juga diperlukan, sebab pimpinan memiliki fungsi penyelia yang dapat mengingatkan dan mengontrol apabila dosen dalam pelaksanaan proses pembelajaran tidak sesuai dengan silabus, pembuatan laporan atau secara administrasi baik dan sebagainya. Itulah pentingnya komunikasi yang dilakukan oleh dosen yang dapat memberikan kepuasan kerja dan semuanya ditujuan bagi kemajuan proses pembelajaran yang ditunjukkan dengan kinerja guna meningkatkan karirnya sebagai seorang dosen.

\section{Simpulan}

1) Motivasi kerja memiliki pengaruh positif dan signifikan terhadap kinerja dosen IKIP Veteran Semarang.

2) Kepuasan kerja memiliki pengaruh positif dan signifikan terhadap kinerja dosen IKIP Veteran Semarang.

3) Motivasi kerja memiliki pengaruh positif dan tidak signifikan terhadap karir dosen IKIP Veteran Semarang.

4) Kepuasan kerja memiliki pengaruh positif dan signifikan terhadap karir dosen IKIP Veteran Semarang.

5) Kinerja dosen memiliki pengaruh positif dan signifikan terhadap karir dosen IKIP Veteran Semarang.

6) Motivasi kerja memiliki pengaruh positif dan signifikan terhadap kinerja serta dampaknya pada karir dosen IKIP Veteran Semarang.

7) Kepuasan kerja memiliki pengaruh positif dan signifikan terhadap kinerja serta dampaknya pada karir dosen IKIP Veteran Semarang. 


\section{DAFTAR PUSTAKA}

Anoraga. Pandji, 2008, Psikologi Kerja. Bandung: Tarsito.

Arikunto. Suharsimi, 2012, Prosedur Penelitian, Suatu Pendekatan Praktik. Jakarta: Rineka Cipta.

Gibson, James L., John M. Ivancevich dan James Jr. Donelly, 2007, Organizations: Behaviour, Structure, Processes. Homewood, III: Richard D. Irwin.

Kusriyanto. Bambang, 2007, Manajemen SDM: Suatu Teori dan Aplikasinya, Yogyakarta: Pustaka Pelajar.

Miarso. S, 2010, Kepemimpinan dalam Manajemen Pendidikan, Bandung: Alumni.

Mulyasa, E. 2009, Pembinaan Profesional dalam Pendidikan, Bandung: Remaja Rosdakarya.

Pasaribu. Bomer, 2008, Tenaga Profesional yang Produktif, Jakarta: LP3ES.

Permendiknas, 2001, Keputusan Menteri Pendidikan Nasioanal Nomor: 36/D/0/2001 tentang Petunjuk Teknik Pelaksanaan Penilaian Angka Kredit Jabatan Dosen, Jakarta: Kemendiknas.

Raymond, A. Noe \& Hollencek, R. John, 2010, Human Resource Management: Gaining a Competitive Advantage, Jakarta: Salemba Empat.

Robbins. P. Stepphen, 2005, Organizationa Behaviour: Concepts, Controversies, Apllications. New Jersey: Prentice Hall, Inc.

Setiaji. Bambang, 2008, Panduan Riset dengan Pendekatan Kuantitatif, Surakarta: UMS Press.

Simamora., J, 2009, Manajemen Sumber Daya Manuaia, Bandung: Tarsito.

Sukmadinata. Nana Syaodih, 2008, Psikologi Kerja, Bandung: Grafindo.

Sanjaya. Wina, 2008, Peningkatan Sumber Daya Manusia. Jakarta: Pustaka Setia.

Uno B. Hamzah. 2009, Manajemen Pendidikan, Yogyakarta: Aditya Media.

Undang-Undang Republik Indonesia Nomor 14 Tahun 2005, tentang Guru dan Dosen, Bandung: Alfabeta. 
Jurnal Pendidikan Agama Islam

Undang-Undang Republik Indonesia Nomor 12 Tahun 2012, tentang Pendidikan Tinggi, Bandung: Alfabeta. 